\title{
Feminist Phenomenology and the Politics of Wonder
}

\author{
Bonnie Mann \\ Department of Philosophy \\ University of Oregon \\ bmann@uoregon.edu \\ Received 14 September 2018; accepted 24 September 2018; published 30 September 2018.
}

\begin{abstract}
The philosophers agree that philosophy begins in wonder. How wonder is understood, however, is not at all clear and has implications for contemporary work in feminist phenomenology. Luce Irigaray, for example, has insisted on wonder as the passion that will renew relationships between women and men, provide a foundation for democracy, and launch a new era in history. She calls on women to enact practices of wonder in relation to men. In what follows I briefly review the most significant claims about wonder in the history of philosophy generally, and as related to the phenomenological practice of the epoché particularly. I consider Irigaray's claims about wonder as they arise out of this tradition, and try to spell out both what is promised to women and what is asked of them through affirmations of wonder. I suggest that this prescriptive notion is at the heart of a new conservatism in "feminist" thought that turns on nostalgia for age-old beliefs about women's proper mode of relation toward men and their accomplishments, and is deeply homophobic. I urge readers to adopt a more critical attitude toward wonder as related to sexual difference by historicizing the inquiry in keeping with the phenomenological practice of Simone de Beauvoir. Drawing on Kant, Beauvoir, and contemporary work by Sara Ahmed, I suggest that there is a politics of wonder at work here which feminists have every reason to question. Reflecting on the politics of wonder also discloses some key features of critical feminist phenomenological practice.
\end{abstract}

Keywords: feminist phenomenology; homophobia; Irigaray; phenomenology; wonder.

\section{Feminist Phenomenology and the Politics of Wonder}

"Philosophy begins in wonder," we are told. Again and again, the tradition proclaims its birth story. From the inception of western philosophy's self-understanding, the capacity to wonder is thought to mark the character of those who are drawn to philosophy. Without 
wonder, no desire, without desire, no philosophy. Later, the phenomenologists declare that when we find ourselves beset by the preoccupations of a social world laden with norms and expectations, when accumulated scientific knowledge leaves us unable to encounter a phenomenon as it is given, we must find our way "back to the things themselves," back to an attitude of wonder that will allow us to meet the world as if for the first time. Indeed, the phenomenological epoché, if it does its work, restores in us precisely this capacity to “"wonder' before the world" (Merleau-Ponty, 1945/2012, p. 14).

Certainly, feminist philosophy, and more narrowly feminist phenomenology, must also begin in wonder. "Wonder is what brought me to feminism," declares the author of Queer Phenomenology, Sara Ahmed, "what gave me the capacity to name myself as a feminist [...] when I first came into contact with feminism, and began to read my own life and the lives of others differently, everything became surprising" (2004/2015, pp. 180-181). What would account for the initiation of movement that is the inception of feminist thought, if not wonder, which Descartes called the first of all passions precisely because it has the power to originate movement?

In feminist thought, wonder is most notably affirmed as the proper beginning point for philosophy by Luce Irigaray and her followers. Irigaray expects a lot from wonder, which she understands not only as the catalyst for inquiry, but also as the mode of engagement that will strip away a history of violent subjection and enable women and men to encounter one another anew, purified of gender's sordid past. This renewed encounter will, in turn, introduce a new era in history and provide the very foundation for democracy. The claims cascade, one into the other, across Irigaray's many writings on sexual difference. But is wonder really so powerful that it can refresh the heterosexual couple after so much time and bring about a "greater happiness in history" (2001a, p. 23)?

The capacious nature of these claims should themselves move a feminist thinker to wonder about wonder. Is wonder really the passion that enables a pure encounter with the phenomenon - for Irigaray, the phenomenon of sexual difference? Does it initiate a return to innocence before history and power, as she suggests? Or does even wonder have its politics? Is there, in fact, a gendered politics of wonder? If there is, how does it play itself out in contemporary feminist philosophy? Today, we refer to the passions as "emotions" or "affects." If wonder is an affect, or at least an affective attitude, or as I would perhaps prefer to say, a modality of engagement saturated by affect - might it be less innocent than we are led to believe? After all, the so-called "affective turn" has drawn on feminist work on the body and queer theory's work on the emotions (Hardt, 2007, p. ix), ${ }^{1}$ along with now abundant empirical research on the affective dimensions of human life, precisely to question whether affects are prior to normativity/ideology/politics. They may be, rather, a key vehicle for the inheritance of norms, for their inscription in the most intimate and essential

\footnotetext{
${ }^{1}$ Some key texts include: Hardt, The Affective Turn (2007); Hoggett and Thompson (Eds.), Politics and the Emotions (2012); Gregg and Seigworth, The Affect Theory Reader (2010); Ahmed, The Cultural Politics of Emotion (2004/2015), and Fisher (Ed.), Gender and the Politics of Shame (2018).
} 
structures of subjectivity across generations and over time. Might wonder, then, have a history and work to re-inscribe a history, even as it allows us to experience a phenomenon like sexual difference "as if" for the first time? And what, then, is the status of the "as if"?

In what follows I briefly review some significant claims about wonder in the history of western philosophy generally, and as related to the phenomenological practice of the epoché particularly. I consider Irigaray's claims about wonder as they arise out of this tradition, and try to spell out what is asked of women through affirmations of wonder, both by Irigaray, and one of her many approving readers, Sara Heinämaa. I urge readers to adopt a more critical attitude toward wonder as related to sexual difference by historicizing the inquiry in keeping with the phenomenological practice of Simone de Beauvoir. Drawing on Kant, Beauvoir, and contemporary work by Sara Ahmed, I suggest that there is a politics of wonder at work here which feminists have every reason to question.

\section{The Power of Wonder}

The philosophers agree that wonder comes first. Plato's Socrates proclaimed that "wonder is the mark of the philosopher. Philosophy, indeed, has no other origin" (1989, 155c-d), Aristotle taught that "it is owing to their wonder that men both now begin and at first began to philosophize" $(1941,892 \mathrm{~b})$, and Descartes called wonder the first passion of the soul. In a passage that Irigaray will cite when she connects wonder to sexual difference, he writes, "when our first encounter with some object takes us by surprise, and we judge it to be new, or very different from what we have previously experienced or from what we expected it to be, this causes us to wonder at it and be astonished" (1649/2015, p. 220). Wonder happens before we have made judgments about whether the cause of our wonder will benefit us or not, which is why it is "the first passion of all" (p. 220). ${ }^{3}$ Wonder has the power to move us, and this is its gift. It enables learning and memory (p. 225). Descartes' methodical doubt can be understood to be the formalized method that he develops with wonder as its originating affect.

The phenomenologists, beginning with Husserl, adopt and adapt these beliefs about wonder. Referring back to the Greeks, Husserl repeats the claim that all philosophy begins in wonder (1935/1965, pp. 171-172), but he augments the earlier versions by noting that through wonder, European man is "gripped by a passion for observing and knowing the world, a passion that turns from all practical interests [...] accomplishes and wants to accomplish only pure theoria" (pp. 171-172). ${ }^{4}$ Husserl explicitly ties wonder and the purified

\footnotetext{
${ }^{2}$ This is Sara Ahmed's insightful question related to wonder, discussed below (2015, p. 179).

3 A lesser cited claim of Descartes is that wonder is associated with esteem and contempt, though Irigaray takes issue with this claim (this association will be important later, however, when we discuss Kant's aesthetic theory of sexual difference) $(1649 / 2015$, p. 220).

${ }^{4}$ The German text reads: "Es ergreift den Menschen die Leidenschaft einer Weltbetrachtung und Welterkenntnis die sich von allen praktischen Interessen abkehrt und im abgesclossenen Kreis Ihrer Erkenntnistätigkeiten und der ihnen gewidmeten Zeiten nichts anderers erwirkt und erstrebt als reine Theoria" (Husserl, 1935).
} 
theoretical attitude it enables, to the "teleological sense of European man" (p. 149), "innate only in our Europe" (p. 155). To be clear about who is included and excluded here, he writes: "In the spiritual sense it is clear that to Europe belong the English dominions, the United States, etc., but not, however, the Eskimos or Indians of the country fairs, or the Gypsies, who are constantly wandering about Europe" (p. 155). In this colonial text, Husserl is at pains to draw our attention to how wonder emerges within history, which he imagines to be the beginning of philosophy/Europe and its preeminent destiny, its unique "teleological sense." What he does not imagine, in this text, is that wonder might disclose history, and particularly its contingent injustices.

The appeal to purity is to be noted here, as the relation between wonder and purity is a curious and important one, which will be reaffirmed in some feminist appeals to wonder. Husserl uses the word "pure" (rein) almost obsessively, often in the titles of his works. While this language is most often understood in a technical sense, turning on a differentiation between empirical and transcendental dimensions of existence, in "Philosophy and the Crisis of European Man," Husserl provides us with the thick moral background for the use of the term, showing us that this differentiation is saturated with value - the moral sense of purification haunts the technical sense. We must wonder, then, what sort of purification wonder instantiates for each thinker for whom it instantiates a purity, what the wonderer is purified of, and why this purification is regarded as both necessary and positive.

When purification is linked to the epoché, it occupies the heart of the phenomenological attitude. Rejecting Descartes' beginning point in radical doubt, where doubt is seemingly obsessed with questions of existence, Husserl instead mandates an abstention from questions of existence. But often this notion of "abstention" seems to extend far beyond the question of existence alone. Husserl himself seems to expand the meaning of the practice of "abstention" or "bracketing," noting that the philosopher "turns from all practical interests" (1935/1965, pp. 171-172) "simply forbids himself [...] to continue the whole natural performance of his world-life" (1954/1970, p. 152). While this is first and foremost a purification from any interest in the actual existence of the phenomenon under consideration, it is also an abstention from any practical investment, for instance in whether I or others are harmed or benefitted by the phenomenon. When Merleau-Ponty presents his own version of the epoché, he cites Eugen Fink's call for the phenomenologists to return to a sense of "wonder' before the world," and elaborates on this movement, "we must—precisely in order to see the world and grasp it as a paradox-rupture our familiarity with it" (1945/2012, p. 1xxvii). ${ }^{5}$

Some articulations of the phenomenological call to wonder, then, suggest that the wonderer is purified of her habituated, practical interests in, judgments about, and taken-forgranted familiarity with the phenomenon. The epoché moves her from a sedimented, established relationship with the phenomenon in which harm and benefit come into play and

\footnotetext{
${ }^{5}$ He then famously claims, however, that "the most important lesson of the reduction is the impossibility of a complete reduction,” (1945/2012, p. xxxviii). This is closer to the understanding of epoché I advocate for feminism.
} 
restores her capacity to encounter it as given, as if for the first time. But even this expanded list barely begins to describe what the wonderer is purified of, since these words ("interests," "judgments," "familiarity," "habit") are themselves able to slide by almost unnoticed, are themselves in need of a kind of purification of/from habit. When we read those words, we might nod along, as if we understand them. But upon reflection they seem devoid of significance. "Interests" are, after all, only lived in their specificity. When I think of "interests" being put out of play in some general sense, the meaning of this is wholly indeterminate until I know what the phenomenon in question is, and what my interests in it might be. Similarly with "judgments" and "habits"- how can I know what it means to me to put these out of play, how should I anticipate how dramatic an act of the will might be required or whether I might be capable of this at all, until I know what is concretely at issue? Without any particular phenomenon in mind, accounts of the epoché 's power to purify provoke an easy faith. The problem with these accounts of the return to wonder is that they are so abstracted from any particular phenomenon, they are liable to lull us back into the very slumber from which we think we've awoken.

So let me take as an example a simple story I often tell my students when I am trying to explain why it is important to put the question of the actual existence of a phenomenon out of play in order to engage in phenomenological inquiry. After a morning run, just coming out of the park near my house and back onto the street where I lived for many years, there was a particular tree stump with a particular shape that, in the dim morning light, would regularly appear to me to be a jack rabbit. Even after having suffered the illusion several times, caught unawares thinking of something else, I would perceive, again, a jack rabbit. This was astonishing, since jack rabbits, which were inhabitants of my geographic childhood home in Eastern Oregon, and which I saw as a child with some regularity, are not inhabitants of my new home in Western Oregon at all. I explain to my students that, from the perspective of an urban wildlife biologist, it is very interesting whether or not this jack rabbit in Eugene exists. But from a phenomenologist's perspective, what is interesting is not the existence of the animal but its meaning. At each appearance, I felt surprise, infused with a sense of well-being and delight, arising in the quick moment before I remembered the rabbit was an illusion; these feelings extended inexplicably beyond my conscious correction of the perception. In fact, the question of existence was quickly resolved the very first time the rabbit appeared, as soon as I moved closer I saw that I was seeing a tree stump, not a jack rabbit - but what a missed opportunity if I were to stop there! Instead, the phenomenologist asks after the meaning of the jack rabbit, the world of meaning in which the jack rabbit and I are entangled, such that passing that stump, over and over again, this felicity.

But what does it mean to put my interests in, judgments about, and taken-for-granted familiarity with the phenomenon out of play? A phenomenological inquiry requires me to proceed, in Husserl's oft-used phrase, "ohne mitzumachen"-without going along with my everyday immersion in the phenomenon. I have to step back and wonder. Why a jack rabbit and not some other appearance? Why does it appear to me? How is it that this illusion sustains itself beyond my conscious refutation of it, someplace beneath conscious 
awareness, such that it reappears regularly? Why is it so instantaneously pleasant, this encounter with the jack rabbit? With effort, I may proceed from these questions to realize something important about what it means for me to have a world, its general structures, how that world is given to me, as a particular life-world, a particular complex of interwoven meanings. In one class, after I had carried on about the jack rabbit for some time, a student from another part of the world, with another history, raised her hand to ask "what is a jack rabbit?" The question was startling in its simplicity, but disclosed something important about the phenomenon - the complex of meanings linked in the appearance of the jack rabbit were not shared meanings — or not shared, at least, with her.

And here the broader sense of abstention becomes more confounding than ever. What the inquiry reveals is not simply general or essential structures of world-having. It is precisely my involvement in this particular lifeworld that must be thematized if meaning is to be disclosed. A precise history and inheritance are put into question, rather than either merely mobilized, or entirely set aside-I try to create a small breath of space between me and my history, in order to catch sight of it. Let us say it is a lifeworld in which a certain relationship to a geography is foregrounded, a certain inheritance in which the jack rabbit symbolizes the wildness of the "wild west" and images of the jack rabbit populate narratives of settler colonial conquest of both "wild nature" and "wild Indians"- - let us say that the jack rabbit is also a comical representative of that wildness, with its huge hind feet and enormous upright ears, a "tamed" image of the wild in fact, which evokes surprise and delight but neither the settler's fear nor the settler's violence - let us say it is also a symbol of survival and endurance as a dessert inhabitant who springs up and startles an observer, not expecting flourishing life in a place devoid of greenery and water - the rabbit evokes the settler's pride at making a living for herself in what she thinks of as a dessert. We could continue these observations at length without exhausting the meanings at play-there is a history here, and not an innocent one. We might wonder what meanings, what sort of lifeworld would be disclosed to another early morning runner coming out of the park. To some, like my student, the jack rabbit would not appear at all. For another runner, with another history, or on another side of the same history, the sedimented meanings, affects and associations will be different.

So only in a very limited sense am I putting my interests, judgments and taken-for-granted familiarity with the phenomenon out of play - only in the sense of a minute hesitation which allows these aspects of the lifeworld which have disclosed themselves to be thematized. Hesitation is not purification, however. I am not redeemed from my settler heritage, as if baptized, but find myself confronting it as a deeply rooted structure of my lifeworld and its meanings, as embedded in my very powers of perception. What brings me, over and over again, this "innocent" illusion and its pleasant affective associations? What makes the image of the jack rabbit powerful enough to defy my conscious awareness of its non-existence? The wondering and its resultant reflections are a "reduction" of sorts, but precisely not a purification, anything but a purification, in fact a de-purification or contamination. My happy encounter with the jack rabbit becomes contaminated, for me, with my own ugly settler history along with its power to produce happy, innocent symbols, 
to mobilize their intimate affective associations in my body. I am moved by wonder, certainly, but from a place of innocence to a place of ambivalence and critique-my innocence is contaminated through this process.

Yet in the phenomenological tradition, the loosening of intentional threads required to undertake an inquiry is very often mistaken for a purification - particularly for a purification from history, politics and power. In "Philosophy and the Crisis of European Man," Husserl seems to simply posit a hypothesis from within the natural attitude, where the taken for granted existence of the "European" as the superior "stock" (Stamm) is never put out of play. "Europe" names the most advanced people on earth, whose special capacities make them/us the pinnacle of humanity. While he makes an assertion about history, in this text, there is no hesitation that might allow the historical provenance, the contingency, the injustice of these beliefs, these effusions, these impassioned declarations, this naive confidence, this "superiority" to appear. Husserl himself suffered profound injustices arising out of the racism that turns centrally on the differentiation of "German" and "Jew," positing the German "race" as something to which a Jew cannot belong, and as the holder of the pure "teleological sense" of mankind.

What we need is a phenomenology that can disclose the contingency of history, not purify us of it. Certainly, it is not the whole of the tradition that fetishizes purification, there are those who often refuse the comforting delusion of an imaginary baptism-Simone de Beauvoir is the clearest example, for me. But the belief in wonder's association with purification is a thread in the tradition that makes its way into contemporary feminist thought, and demands, therefore, reconsideration from within feminism. ${ }^{6}$

One of the clearest contemporary examples of wonder-as-purification is to be found in the writings of Luce Irigaray. The second and third periods of Irigaray's work seem, in fact, to be founded on the notion of a momentous purification of the two subjects (man and woman) through wonder. It involves a heavy prescription related to wonder, in other words, a mandate to wonder, which is primarily a mandate for women. Wonder's power to purify is understood to be the very foundation of ethics, democracy and the future. Sara Heinämaa, one of Irigaray's most careful and insightful readers, develops Irigaray's trajectory further by affirming the normative force of wonder in relation to how women should read androcentric philosophy.

In what follows, I initiate a critical phenomenological investigation of the feminist call to wonder in order to question its normative force as an affective mode with purifying power. I hope to show that wonder has no such power in relation to interests, judgments, habits,

\footnotetext{
${ }^{6}$ In one sense, we might point to the tradition of hermeneutic phenomenology as a place where the notion of "purification" is resisted. In another sense, that tradition has its own modes of purification that should be criticized. Mariana Ortega's feminist criticism and appropriation of Heidegger is an example of a feminist adaptation of the hermeneutic tradition in phenomenology (2016). Concerns related to mine are to be found in Oksala (2016), and Ahmed (2004/2015). Unlike Oksala, who turns to Foucault, I find the sort of phenomenology I am calling for in Beauvoir. See my essays on Beauvoir's phenomenology (Mann, 2012, 2017, 2018).
} 
in short, in relation to history. In other words, while wonder might enable us to thematize these, it has no baptismal power; wonder can't wash us clean.

\section{Wonder as Women's Historical and Philosophical Task}

Referring in some detail to Descartes, Irigaray carries on the philosophical tradition that affirms wonder by acknowledging that "the living being has need of wonder in order to move" (1984/1993, p. 73). She adapts the traditional affirmation of wonder for feminist thought, making wonder a key notion in her philosophy of sexual difference. Here, too, wonder is first, "the passion that inaugurates love and art" (p. 82). Reading Irigaray, Heinämaa concurs, noting that wonder "precedes all evaluations of the object, of its suitability (convenance), usefulness, or harmfulness to the maintenance and well-being of the mind-body union" (2017, p. 214).

In this work too, wonder promises purification. Using the metaphor of "the machine" for the force of social prescription, the question Irigaray raises is whether or not we can "look at, contemplate, wonder at the machine from a place where it does not see us" (1984/1993, p. 74). This is a place where we might hope to "return to ourselves as living beings who are engendered and not fabricated" (1996, p. 14), a place where we are "not yet assimilated or disassimilated as known" (1984/1993, p. 75). "Before and after appropriation," she asserts, "there is wonder" (p. 74). Reading Descartes, Irigaray describes the place in the brain where he locates the "sudden surprise of the soul" at things which appear "rare and extraordinary" (p. 77), characterizing it as "still untouched," as "tender and not yet hardened by past impressions" (p. 77). This "space of freedom" (p. 76), "protects the movement's lightness" (p. 80). It "constitutes an opening prior to and following that which surrounds, enlaces" (pp. 81-82). This language of innocence ("untouched' "tender" "not yet hardened" - which might also be a language of virginity), attaches a certain affective history to the purification underway. We are relieved, aren't we - comforted by the idea of innocence restored, by the evocation of childlike softness, by the image of a pure and unsullied virginal body? Or someone is comforted. Not "we" feminists, exactly, but "we" who stand in a tradition with an enormous historical burden on its shoulders - that load of systematic exclusions, subordinations, violations over centuries, makes us sick doesn't it? It weighs us down. Wouldn't it feel good to return to a time before knowledge and its responsibilities, to be light again?

Wonder becomes the key to Irigaray's philosophy of sexual difference. It is wonder that will allow for the "renewal and recreation of intersubjectivity" (Heinämaa, 2017, p. 210) between man and woman, men and women - a "new alliance between the female and male genders" (Irigaray, 1996, p. 11). It is wonder that "starts to reveal the reality and fecundity of sexual difference" (p. 8). Irigaray's explicit intention is to find a way to overcome the historical structures that have kept women subordinated to men, to overcome a universalizing and totalizing vision of masculinist subjectivity. "The difference between the genders," she writes, "appears [...] as the most radical limit opposed to the totalizing will of 
the subject" (1994/2001a, p. 6). But while Irigaray has sometimes put forth concrete proposals for social reorganization, often in her texts she seems to be proposing a return to wonder in the way that too many in the phenomenological tradition have, as an act of the will, a willed ignore-ance - abstention from, bracketing of - the whole sordid history of women's subordination to men. The passion of wonder is meant to strip away our immersion in all of that and get us down to the essential difference, the originary, ontological difference, between women and men.

She is aware that her enthusiasm for sexual difference as an irreducible, ontological difference might easily be read as a return to male supremacist versions of sexual differencewhich in their traditional form insist on the eternal and ahistorical nature of sexual difference at the same time that they (as Irigaray and Beauvoir before her taught us) ${ }^{7}$ make the feminine a mere mirror of the masculine thus erasing difference in the name of difference; Irigaray tries to avert this reading. Her efforts are explicitly marked in her text by the insertion of the word "to" in the sentence, "I love to you." "To" is supposed to create an interval, a distance, a hesitation, that will put an end to possession and prevent the collapse of two into one. "To be in favor [...] of the difference between man and woman cannot be interpreted as a return to a hierarchical situation," she writes (1994/2001a, p. 24). But isn't this an open question, not a closed one? Is forbidding this interpretation sufficient to forestall it? I don't know what "being in favor" of sexual difference in some general sense means. Isn't it a question, rather, of what sort of sexual difference, how and in what context and with what arguments one defines, defends and champions sexual difference?

Irigaray has a favorite example, her friendship with the Italian politician Renzo Imbeni, to whom she dedicates I Love to You. She is effusive about this relationship and its possibilities, calling their first conversation "a miracle" (1996, p. 7). She describes him as "alive," "daring and unsubmissive," "innovative," "prudent," a man who "progresses without accumulating" and "shares without complacence," "only makes promises he can keep," and in whom "it is possible to have faith" (p. 15). In Democracy Begins Between Two, Imbeni appears as a member of an idealized heterosexual couple, along with Irigaray herself.

A democratic politics [...] can only be based on [...] a two which comes into existence between a man and a woman who meet and respect each other in their irreducibility. This couple embodies the ultimate concrete reality of the community [...] We have to begin from a true concrete universal, that is, from the relationship between a man and a woman who, in faithfulness to their bodily and spiritual differences, maintain the ideal of their own gender in alliance with another gender. My encounter with Renzo Imbeni has led me to hope that this work is possible [...] During our debate [...] I sensed that Renzo Imbeni entertained an ideal which could meet mine, and that he was man enough, and I woman enough, for us to be able to remain between two. (1994/2001a, p. 26)

\footnotetext{
${ }^{7}$ While Irigaray and others have accused Beauvoir of advocating the elimination of sexual difference, which amounts, for these critics, to a capitulation to masculinism, Beauvoir has a much more nuanced position. For a review of this criticism and close textual reading of Beauvoir in response, see Mann (2008).
} 
Before Imbeni, we have already learned about the power of wonder. "This first passion is indispensable not only life but also or still to the creation of an ethics. Notably of and through sexual difference" (1984/1993, p. 74). After Imbeni, the claims crescendo, so that wonder enables a heterosexual coupling that can renew "the foundations of democracy" (1994/2001a, p. 118). Her entire theory of democracy, she confesses, is simply a meditation "on how a political project, as, too, a civil relation between Renzo Imbeni and Luce Irigaray could work" (118). This relationship has allowed her to believe that "the difference between ma(e)n and woma(e)n appears as the possible model for a new era in history" (p. 13). The man/woman couple is the generative site for "energy, creativity, happiness" (p. 104), including "a greater happiness in history" (p. 23). Wonder can initiate all of these wonders precisely because it frees us from an egregious history in order to allow a new history to begin.

But does it? As we follow Irigaray's thought on this topic there are passages in her work that take on a heavily prescriptive tone. She speaks of happiness between women and men as "our primary cultural obligation," which requires that we give up the goal of equality with men (1996, p. 15). In case we mistake the "our" here as one that includes women and men equally, or at least reciprocally, Irigaray makes herself clear: "I am often reproached for asking so much of women," she writes. "It is true that I expect a great deal, especially of myself and so, too, of all women. This is because I believe that women can open up a new era in History, in other words, a possible future for humanity. So I am constantly asking them not to fall asleep, to remain awake so that they can behave in an attentive and coherent way to be sure of accomplishing the historical task that is theirs" (1994/2001a, p. 95). In keeping with the tradition of affirming a "teleological sense" belonging to some special group in history, Irigaray assigns women the task of fixing all that has been wrong in the history of heterosexual relations. "The historical accomplishment of this passage from the subject as one and singular to the existence of two subjects of equivalent value and dignity seems to me an appropriate task for women as regards both philosophy and politics" (p. 140). Why is it our task (women readers), and not yours (men readers)? Because of our specific sexual difference, she claims (echoing the traditional masculinist excuse for assigning emotional labor to women), because women are better at relationships than men, "better able to commit themselves to a relationship between two, to the relationship with the other" (p. 140). While this may seem to be a displacement or replacement of the European male as the bearer of the teleological sense of humankind, we should hesitate before drawing this conclusion.

How are women to assume their special historical purpose? What is the nature of this undertaking? While Irigaray spends a great deal of time discussing women's relation to their own gender, particularly the mother/daughter relation (Irigaray, 1994/2001b, pp. 30-39), and has sometimes said that same-sex relationships might allow women to re-work and experience a positive relationship with "the same," and thus develop the autonomy of the 
female gender. ${ }^{8}$ These are preliminary steps. They allow us (women) to center ourselves in our own gender in order to enact our historical task in relation to men. The real work women are called on to do is to restore the heterosexual couple as the motor of history through first regaining a sense of our own autonomy, then restoring to men their autonomy and transcendence. Speaking of her own path, which is hers "probably because I am a woman," the goal of which is to "cultivate the relation between two subjects," Irigaray makes clear that women's historical task ultimately has to do with enabling a "new" masculine transcendence. "What I have perceived through him," she writes, "I thus return to him. I reveal to him a part of his being which has revealed itself to me, and I invite him to inhabit his own being in a better way. I try in this way to become of assistance to him, while all the while respecting what is mysterious in him, the invisibility of his interiority" (1994/2001a, p. 116). Ultimately, women's historical task is to "construct the transcendence of the other" (pp. 138-139), through wonder.

This task is reformulated in an essay by Sara Heinämaa in which she considers Irigaray's call to wonder, also, as a call to a specific kind of relationship to the masculinist western philosophical tradition. On her reading, Irigaray reveals not only the "normative necessity of wonder in relations between men and women" (2017, pp. 209-210), but also gives women a prescription for how to read androcentric philosophy. "What we have is not just an argument for wonder," Heinämaa claims, "but also an attempt at establishing a wondering attitude toward philosophical texts and at opening a new space between a female reader and an androcentric tradition. The aim is not just to write about wonder but also to read in wonder" (p. 220). Earlier in the essay, Heinämaa has written approvingly about the power of wonder. While for Descartes, wonder "precedes evaluation," in phenomenology, Heinämaa claims, it "means canceling evaluations and judgements already in operation," it returns us to "a state of pure alertness, free of all positing of validity and existence" (p. 218). Is the feminist reader, then, to go back to reading androcentric philosophical texts purified of her own judgments and evaluations? Does the epoche take the form of a baptismal event? It promises to return the feminist reader to a state of innocence before feminist consciousness and its judgments, yet Heinämaa herself has named this tradition "androcentric," making a clear feminist judgment about it, as she calls for cancelling judgments in order to read in wonder. This judgment destabilizes her claims - making us wonder whether it is really possible or desirable to reverse feminist consciousness in this way.

\footnotetext{
${ }^{8}$ Many readers understood Irigaray's early work to include a positive political call to lesbianism. In her middle and later period, however, her work deeply contradicts this reading. If there is a call to lesbianism in the early work, it is as problematically romanticized as is her faith in idealized heterosexuality in the later work. I find the later work to be almost unbearably homophobic, and wish that readers in English speaking countries would be far bolder in making this criticism. Scholars turn somersaults to avoid facing what Irigaray actually says on the matter. One of the most glaring examples is in the "Prologue" to I Love to You, where she refers to lesbian relationships as "delusive, alienating, and utopian" and claims that lesbian attraction "exiles [women] from the construction of a specific will and history" (1996, p. 5).
} 
Could it be that calls to wonder in feminist philosophy are calls for such a reversal? Should we return to a state of innocence in relation to men and their texts? Does wonder mandate a retreat from feminist judgment and anger and disgust - from feminist interests - as my reading suggests? The normative claims related to wonder travel under the banner of the "new:" promising a "renewal" of certain heterosexual couplings (man/woman, womanreader/men's-texts), promising that we might be purified of the interests and judgments and evaluations which, let's face it, make feminists tired and make men tired of us. Irigaray explicitly promises and mandates happiness, as the outcome. But is there anything new here? Or are we nostalgic for an old history?

\section{Wonder Historicized}

Another feminist account of wonder moves us in a different direction. I briefly mentioned Sara Ahmed's report that, for her, feminism began in wonder. "Wonder is what brought me to feminism," she writes $(2004 / 2015$, p. 180), wonder is that "affective relation to the world" (p. 178) that provokes "an encounter" which in turn "works to transform the ordinary, which is already recognized, into the extraordinary" (p. 179). Ahmed does not see her relationship to feminism as one that is mired in "negation," but rather "something more creative, something that responds to the world with joy and care," yet also involves "the feelings of pain, anger or rage" that are commonly associated with feminism (p. 179).

I remember my own astonishment when, at age 19, I first read the words of a feminist who questioned the supposed maleness of god. "If god is male, then the male is god," she wrote (Daly, 1974/1985, p. 19). Having grown up in a fundamentalist Christian household in a state of inchoate unease, with daily Bible readings during much of my childhood, I was struck dumb by the audacity of the critique and the world of possibility laid open at my feet, by the bold lack of reverence, the explicit rejection of reverence in fact, as the proper attitude for women to bring to relations with men and the gods made in their image. I faced the text with my mouth hanging open, in a state of shock brought on by the so-very-familiar made strange. I felt I had been drawn to the edge of a precipice, that having the courage to look over would un-determine a future I had been led to regard as settled destiny: manmarriage-children - in a matrix of god-ordained subordination. It is fair to say that my encounter with that sentence initiated a feminist life, in my case, a lesbian feminist life. I spent my winter vacation that year breathless, reading every word of Beauvoir's The Second Sex, as the necessary was reworked before me and appeared contingent. To be sure, I was in a state of wonder, but this wonder was stripping me of innocence, giving form to latent anger and frustration at a history that had been presented to me as determinate nature. I had never been able to place my unease in a coherent narrative, but now a story unfolded. At the same time as the past reconfigured itself, a formerly closed future yawned open - that was a winter of both joy and fear. 
In a sense, I was seeing the world "as if" for the first time. But as Ahmed asks, "what is the status of the 'as if'? Does such an impulse require the erasure of history [...]" (2004/2015, p. 179)? Ahmed's answer to this question moves in the opposite direction from Irigaray's: "I would suggest that wonder allows us to see the surfaces of the world as made, and as such wonder opens up rather than suspends historicity. Historicity is what is concealed by the transformation of the world into 'the ordinary', into something that is already familiar, or recognizable" (pp. 179-180). In my case, what I could suddenly see that I couldn't before was the terrible, contingent, man-made maleness of god-the subordination it justified, and the thick, choking injustice it ordinarily concealed. I was sick with new knowledge, and drunk on possibility, burdened and freed.

Ahmed's work provides us with another caution that I would raise in relation to Irigarayan wonder, particularly its promise of happiness. In The Cultural Politics of Emotion, rejecting the idea that emotions are internal to a subject in any strict sense, she tries to understand how emotions circulate in social contexts, how they "stick" to certain objects or events. According to Ahmed, emotions produce investments, normatively mandate particular kinds of social relationships, work to maintain modes of dominance and subordination, and produce passionate affective loyalties that function to animate certain interestsnationalism is one of her key examples (2004/2015). ${ }^{9}$

Happiness, Ahmed cautions, "can be promised as a return for investment in social norms" (2004/2015, p. 196). Girls have long been disciplined into heterosexual conformity through promises of happiness. A girl is told her wedding day will be "the happiest day of her life," and the repeated telling cements a social investment in marriage as a site of happiness, whether or not the actual feeling accompanies the actual event. An unmarried woman is tragic in that she has never achieved the pinnacle of her own happiness. In another context, I have written about Beauvoir's account of the temporality that structures an adolescent girl's relation to her future (Mann, 2018, p. 69). This temporality is most easily recognized in fairy tales in which the prince's kiss brings the girl to life (begins or renews time), the prince's proposal restores her social worth, and the marriage inaugurates an end-of-time called "happily ever after." While I did not previously frame this discussion explicitly in terms of the promise of happiness, Beauvoir's description of the structure of time, which entraps the adolescent girl and suspends the meaning of her life in waiting, hinges precisely on such affective investments in future events. The girl's lifeworld is replete with images, stories, patterns of behavior and language, material arrangements and cultural practices that collectively, over time, imbue her destiny — "she is destined for man," Beauvoir writes (1949/2010, p. 359) — with such significance that the girl is persuaded to sacrifice her own world-making and value-creating capacities to this imagined future.

The prescribed destiny, and the proper behavior in the girl or woman who aspires to fulfill it, is historically entangled with a demand that women "wonder" at the male sex. Kant's pre-critical treatise on aesthetics and education contains a chapter in which he articulates

\footnotetext{
${ }^{9}$ Ahmed rejects the notion that emotions and affects are clearly distinguishable, as if emotions occupy a cultural space while affects occupy a more instinctual or pre-social realm — both work to inscribe values on bodies.
} 
the nature of sexual difference by differentiating between the beautiful and the sublime. He has already described the proper response to one sort of sublime experience, which he calls the "noble sublime" as wonder (Bewunderung) when he names men the noble sex (edle Geschlecht) and associates men (particularly German men) with the sublime. Then he essentially prescribes wonder at men, to women. In a woman, "the sublimity of her soul shows itself only in that she knows to treasure these noble qualities so far as they are found in him" he writes (1763/1960, p. 94). The "dignity and sublime qualities" of men are the proper focus of women's education and moral development (p. 94). What a man demands of a woman is not love but esteem (hochachtung). Women might demand love from men, he notes, but cannot properly expect esteem (p. 95).

It is this sort of history that prompts Beauvoir to note that the material relations structuring male dominance are accompanied by a heavy handed existential mandate. Women are constrained to perform certain kinds of labor for men, but also to make themselves of service to men's ontological and existential ambitions. Recognizing that many men "seek a glowing image of admiration and gratitude, deified in the depths of a woman's two eyes" (1949/2010, p. 202), Beauvoir tells us, the history of domination mandates pious adoration (p. 359) such that "love becomes a religion for her" (p. 684). In other words, a world structured by male domination situates women to love idolatrously - as if in a state of religious wonder. But she loves/worships in order to try to regain herself in the end. Her "dream of annihilation is in fact an avid will to be" (p. 687), what she seeks is "to exist sovereignly by effacing [herself] within the other" (p. 690). This is a project that is bound to fail, as Beauvoir so astutely teaches; it collapses into resentment and despair (p. 500, 508). ${ }^{10}$ Meanwhile, the reorientation of a woman's subjectivity with men and their needs at the center (which occurs in adolescence), makes her complicit in her own subordination. As Sandra Bartky famously claimed, in her phenomenological account of women's emotional caretaking related to men, what men get out of the emotional aspect of these arrangements (what they get out of the material aspects is more obvious), is the "conferral of status" the "paying of homage," "an affirmation of male importance that is unreciprocated" (Bartky, 1990, p. 108). She warns women, in keeping with Beauvoir's earlier claims, that "the consistent giving of what we don't get in return is a performative acknowledgement of male supremacy and thus a contribution to our own social demotion" (p. 109); it amounts to an act of "collective genuflection" (p. 109).

Should we think this is all ancient history and we have no need, today, to worry about such corrosive dynamics, we need only turn to the recent work of the young philosopher Kate Manne who, in her meticulously argued book, shows that the most intransigent forms of male supremacy today, at least in her own context, are those that involve "asymmetrical moral support roles" (2018, p. xiii) an "uneven, gendered economy of giving and taking" (p. 107). A member of the \#metoo generation, Manne states, "my view is that a significant amount of misogyny in my milieu serves to police and enforce these social roles, and extract moral goods and resources from [...] women" (p. xiv). In this context, men are

\footnotetext{
${ }^{10}$ Beauvoir's literary depiction of this destruction is aptly titled The Woman Destroyed (1969).
} 
taught a "potent sense of personal entitlement" (p. 76) related to who owes what to whom (p. 108, 116). This proprietary sense infuses social environments, where men exhibit "a sense of illicit entitlement" both to sit in judgement of women and to be the "object of care and admiration" provided by women (p. 171) — these kinds of "goods" are experienced by some men as an existential necessity which women owe to them (p. 302).

Irigaray, again, promises happiness. And again, the promise of happiness is linked to women devoting themselves to men's "ontological and moral ambitions" (de Beauvoir, 1949/2010, p. 159). "I have searched hard for a way of recognizing the other: man, whose body and spirit remain unknown to me. I have had to renounce all forms of possessiveness, of appropriation, never saying me or mine when speaking of the other" (Irigaray, 1994/2001a, p. 28). Instead, she makes herself "of assistance to him," through her wonder at him, revealing to him something that she has "perceived through him" and must "return to him" (p. 116). These passages bear such a heavy resemblance to an ugly history in which a woman's role is to mediate a man's relation with himself, that Irigaray must do more than state that she is not reaffirming a hierarchical relation here, she must do more than add "to" to the phrase "I love you." She must show us how it is that calling for a renewal of a very old mandate (though elevated, as so often in times of political trouble, to world-historic significance), and calling for this mandate as women's unique historical task without any pretensions to reciprocity or equality, while claiming to shed the burden of entrenched historical relations of domination and subordination by magic, could possibly amount to anything other than a repetition of the same. Here, conservatism emerges purportedly from within feminism; the will to sustain the rules of an old relation is dressed up as wondrously new. ${ }^{11}$

Beauvoir has a very different view about how relationships between women and men might be re-configured. "Love-religion leads to catastrophe" (1949/2010, p. 705), she writes, "her love itself disfigures her, demolishes her; she is no more than this slave, this servant, this too-docile mirror, this too-faithful echo" (p. 704). For her, "authentic love must be founded on reciprocal recognition of two freedoms" (p. 706), it must "take on the other's contingence" (p. 694). There is no wonder here, but awareness of "his lacks, his limitations, and originary gratuitousness"; she recognizes that she is in relation with another human being in history, not with a minor god (p. 694). For Beauvoir, the reciprocal recognition of two freedoms is a possibility between any two (or more) subjects - there is no ontological privilege for the heterosexual couple, no promise that democracy will find its foundation and history will find its happiness when women are properly able to wonder at men, again. There is no epoché that can strip away generations of violence and exclusion and return women to a state of innocence in relation to men and their philosophical writings. There is, on the one hand, the fight for material change (women must become economically independent through collective struggle), and on the other hand, the complex, ambiguous, fraught, demanding, joyous, outraged aspiration to become an independent

\footnotetext{
${ }^{11}$ See Beata Stawarska's related distinction between conservative and transformative strands in feminist phenomenology (in press).
} 
woman in the existential sense. In Beauvoir's phenomenology, the epoché is a matter of work, not the simple act of a mind willing itself free of its prejudices. It happens over time, imperfectly, through the committed engagement of a plurality of points of view, through an ongoing reflective process in which there is a constant oscillation between the particular and the general. ${ }^{12}$ Putting one's prejudices out of play involves changing the existential conditions of one's life.

\section{Feminist Phenomenology}

What these reflections might mean for feminist phenomenology as a philosophical practice must be worked out carefully, over time, with attention to the concrete phenomena that are the objects of concern for feminist thinkers. Sexual difference is only one such concern. Gender in relation to racial and class stratification, nationalism, the inherited "goods" and violent harms of settler colonialism, economic life broadly, the changing climate, our relationships with other-than-human creatures, and the affective and political dimensions of each of these, are all matters of feminist concern (to name only what is most obvious). Following Beauvoir, an impulse to historicize is an essential dimension of feminist wonder. Put differently, feminist phenomenological practice, including feminism's version of the epoché, cannot be imagined as a baptismal event. Feminist phenomenology, like all feminist thought, will begin in wonder, to be sure, but without fantasies of purification. Contamination, ambiguity and complicity are germane to the practice.

Does this mean that feminist phenomenology will only discover dimensions of sexual difference or existence more generally insofar as they are imbricated in structures of power and violence? My answer to this question is an emphatic "no." But to imagine that we might purify our relationship with the phenomenon under consideration of such relations in advance, rather than discovering the plurality of meanings disclosed through the process of investigation, is anathema to feminist thought. There is no willful setting aside of history, politics or power-but there may be meanings excessive to history, politics and power. There are existential structures that have transhistorical implications (a simple example is the human creature's dependence on air, light, water, and the care of anotherwhich I take to have ethical implications at any time, in any human society). If there are broad, universal dimensions to be discovered, they are never easily disentangled from the historical specifications that shape any lifeworld encounter with them.

In addition to these broad, essential dimensions of existence, there are also singular meanings at play. The jack rabbit is perhaps a good example here. The historical entanglements that mark the meanings of the jack rabbit don't foreclose the disclosure of other meanings, perhaps in complex, impure, not completely distinguishable forms. As a teenager, I spent a great deal of time running down the roads and over the hills around my small rural town as an escape from certain difficult things in my life for which no other manner

\footnotetext{
${ }^{12}$ For a more detailed account of Beauvoir's phenomenological method see Mann (2018).
} 
of escape presented itself at the time. On my favorite run, straight up over a series of small sagebrush hills, the occasional jack rabbit leaping away at my approach was perhaps expressive of that space of freedom in a way that is singular to me and my particular history. The jack rabbit's meaning exceeds, but does not exist in radical independence from the settler history I discussed above. This is to say that the meanings disclosed by the jack rabbit, real or imagined, may also include meanings specific to uniquely individual circumstances, a singular lifeworld - neither reducible to, nor entirely separable from, the historical matrix of meanings.

If wonder comes first, if wonder initiates, if it sets a feminist mind into motion, the inquiry it instantiates is not set up in advance with guardrails to keep out history and politics, or anger and recrimination, or joy and love. Neither responsibility for the past nor hope for the future are excluded. Neither interests, nor judgements, nor deep affective investments are kept at bay. Each of these comes into view, never purified of the others, when wonder does its work.

\section{References}

Ahmed, S. (2006). Queer phenomenology: Orientations, objects, others. Durham, NC: Duke University Press.

Ahmed, S. (2015). The cultural politics of emotion (2nd ed.). New York, NY: Routledge (Original work published 2004).

Aristotle. (1941). Metaphysics (W. D. Ross, Trans.). In R. McKeon (Ed.), The basic works of aristotle $\left(35^{\text {th }}\right.$ ed.). New York, NY: Random House.

Bartky, S. (1990). Femininity and domination: Studies in the phenomenology of oppression. New York, NY: Routledge.

Daly, M. (1974). Beyond god the father: Toward a philosophy of women's liberation. Boston, MA: Beacon Press.

de Beauvoir, S. (1969). The woman destroyed. New York, NY: Pantheon Books.

de Beauvoir, S. (1976). Le deuxième sexe ii: La expérience vécue (Vol. 2). Paris, France: Gallimard. (Original work published 1949)

de Beauvoir, S. (2010). The second sex. (C. Borde \& S. Malovany-Chevallier, Trans.). New York, NY: Alfred A. Knopf. (Original work published 1949)

Descartes, R. (2015). The passions of the soul (M. Moriarty, Trans.). In The passions of the soul and other late philosophical writings. Oxford, UK: Oxford University Press. (Original work published 1649)

Fisher, C. (2018). Gender and the Politics of Shame: A Twenty-First-Century Feminist Shame Theory. Hypatia: A Journal of Feminist Philosophy, 33(3). 
Gregg, M., \& Seigworth, G. J. (Eds.). (2010). The affect theory reader. Durham, NC: Duke University Press.

Hardt, M. (2007). Foreward: What affects are good for. In P. T. Clough \& J. Haley (Eds.), The affective turn: Theorizing the social. Durham and London: Duke University Press.

Heinamaa, S. (2017). Wonder as the primary passion: A phenomenology of social encounters. In L. Dolezal \& D. Petherbridge (Eds.), Body, self, other: The phenomenology of social encounters. Albany, NY: State University of New York Press.

Hoggett, P., \& Thompson, S. (Eds.). (2012). Politics and the emotions: The affective turn in contemporary political studies. New York, NY: Continuum Books.

Husserl, E. (1935). Die Krisis der europäischen Menschentums und die Philosophie. In Bibliotheca Augustana. Retrieved September 20, 2018 from https://www.hs-augsburg.de/ harsch/germanica/Chronologie/20Jh/Husserl/hus_kris.html

Husserl, E. (1965). Philosophy and the crisis of European man. (Q. Lauer, Trans.). New York, NY: Harper and Row. (Original work published 1935)

Husserl, E. (1970). The crisis of European sciences and transcendental phenomenology. (D. Carr, Trans.). Evanston, IL: Northwestern University Press. (Original work published 1954)

Irigaray, L. (1993). An ethics of sexual difference. Ithaca, NY: Cornell University Press.

Irigaray, L. (1996). I love to you: Sketch of a possible felicity in history. (A. Martin, Trans.). New York, NY: Routledge.

Irigaray, L. (2001a). Democracy begins between two. (K. Anderson, Trans.). New York, NY: Routledge. (Original work published 1994)

Irigaray, L. (2001b). To be two. (M. R. a. M. Cocito-Monoc, Trans.). New York, NY: Routledge (Original work published 1994)

Kant, I. (1960). Observations on the feeling of the beautiful and sublime. (J. T. Goldthwait, Trans.). Berkeley and Los Angeles, CA: University of California Press, LTD (Original work published 1763).

Kant, I. (2012). Beobachtungen über das gefuhl des schönen und erhabenen. In N. H. Langkau \& J. Srna (Eds.). Retrieved September 20, 2018 from http://www.gutenberg.org/files/41197/41197-h/41197-h.htm

Mann, B. (2008). Beauvoir and the question of a women's point of view. Philosophy Today, Summer, 136-148.

Mann, B. (2012). Gender as justification in Simone de Beauvoir's Le Deuxième Sexe. Sapere Aude: Journal of Philosophy, 3(6), 200-213.

Mann, B. (2017). Beauvoir against objectivism: The operation of the norm in Beauvoir and Butler. In B. Mann \& M. Ferrari (Eds.), “On ne naît pas femme: On le devient...": The life of a sentence. New York, NY: Oxford University Press.

Mann, B. (2018). The difference of feminist phenomenology: The case of shame. PUNCTA: Journal of Critical Phenomenology, 1, 41-73.

Manne, K. (2018). Down girl: The logic of misogyny. New York, NY: Oxford University Press. 
Merleau-Ponty, M. (2012). The phenomenology of perception. (D. Landes, Trans.). New York, NY: Routledge. (Original work published 1945)

Oksala, J. (2016). Feminist experiences: Foucauldian and phenomenological investigations. Evanston, IL: Northwestern University Press.

Ortega, M. (2016). In-between: Latina feminist phenomenology, multiplicity and the self. Albany, NY: State University of New York Press.

Plato. (1989). Theaetetus (F. M. Cornford, Trans.) In E. Hamilton \& H. Cairns (Eds.), The collected dialogues of plato (14 ${ }^{\text {th }}$ ed., pp. 845-919). Princeton, NJ: Princeton University Press.

Stawarska, B. (in press). Subject and Structure in Feminist Phenomenology In S. C. Shabot \& C. Landry (Eds.), Emerging Trends in Feminist Phenomenology. New York, NY: Rowman \& Littlefield. 